\title{
ANALISIS KELAYAKAN USAHA BUDI DAYA IKAN NILA (Oreochromis niloticus) SISTEM KARAMBA JARING TANCAP DI DESA PASLATEN KECAMATAN REMBOKEN KABUPATEN MINAHASA Injilly V. Wowor ${ }^{1}$; Jeannette F. Pangemanna2; Vonne Lumenta ${ }^{2}$ \\ 1) Mahasiswa Fakultas Perikanan dan IImu Kelautan Universitas Sam Ratulangi, Manado. \\ 2) Staff Pengajar Fakultas Perikanan dan IImu Kelautan Universitas Sam Ratulangi, Manado. Koresponden email: injilly.wowor@yahoo.co.id
}

\begin{abstract}
This study aims to determine the feasibility of cultivation of Tilapia system net cages step in the Village Paslaten District of Remboken Minahasa based business feasibility analysis net cages step for determining operating profit $(O P)$, net profit $(\pi)$, the profit rate $(P R)$, benefit cost ratio $(B C R)$, profitability, break-even point $(B E P)$ and payback period (PP). The results of the business analysis system aquaculture net cages Paslaten step in the Village District of Remboken eligible to run for Value operating profit (OP) is Rp. 73.564 million. Value of net profit or Rp absolute advantage. $65,994,296$. Profit rate (PR) of $98.45 \%$. The value of the benefit cost ratio (BCR) more than 1 is 1.98 . Business profitability into the category of nice because more than $100 \%$, ie $166 \%$. Break even point sales of Rp. $13,517,328$ and BEP unit $540 \mathrm{~kg}$ with a payback period of 7.2 months or seven months and six days. Based on these calculations, the business system Tilapia aquaculture net cages Paslaten step in the Village District of Remboken feasible.
\end{abstract}

Keywords : cultivation, net cages, feasibility, financial

\begin{abstract}
Abstrak
Penelitian ini bertujuan untuk mengetahui kelayakan usaha budi daya ikan Nila sistem karamba jaring tancap di Desa Paslaten Kecamatan Remboken Kabupaten Minahasa berdasarkan analisis kelayakan usaha karamba jaring tancap untuk menentukan operating profit (OP), net profit ( $\pi)$, profit rate $(P R)$, benefit cost ratio $(B C R)$, rentabilitas, break even point (BEP) dan payback period (PP). Hasil analisis usaha budi daya ikan sistem karamba jaring tancap di Desa Paslaten Kecamatan Remboken layak untuk dijalankan karena Nilai operating profit (OP) yaitu Rp. 73.564.000. Nilai net profit atau keuntungan absolut Rp. 65.994.296. Profit rate (PR) sebesar $98,45 \%$. Nilai benefit cost ratio (BCR) lebih dari 1 yaitu 1,98. Rentabilitas usaha masuk dalam kategori baik sekali karena lebih dari $100 \%$ yaitu $166 \%$. Break even point penjualan sebesar Rp. 13.517 .328 dan BEP satuan $540 \mathrm{~kg}$ dengan jangka waktu pengembalian 7,2 bulan atau tujuh bulan enam hari. Berdasarkan perhitungan tersebut maka usaha budi daya ikan Nila sistem karamba jaring tancap di Desa Paslaten Kecamatan Remboken layak untuk dijalankan.
\end{abstract}

Kata Kunci : budidaya, jaring tancap, kelayakan, finansial

\section{PENDAHULUAN}

Pembangunan sektor perikanan dan kelautan sebagai bagian dari pembangunan nasional bertujuan untuk mengusahakan agar setiap kegiatan perikanan dan kelautan dapat dilakukan oleh bangsa Indonesia, baik berkegiatan produksi, pengolahan maupun pemasaran. Hal tersebut pada hakekatnya merupakan penjabaran operasional dari tujuan jangka panjang yang ingin dicapai untuk meningkatkan kesejahteraan dan taraf hidup nelayan maupun petani ikan (Dahuri dkk, 2001).

Perairan umum yang memiliki potensi yang cukup besar untuk usaha budi daya ikan antara lain : waduk, danau, bendungan pengendali dan genangan air lainnya. Budi daya perikanan berpotensi dalam meningkatkan pendapatan masyarakat, memperluas kesempatan kerja dan 
kesempatan berusaha serta penghasil devisa negara (Pontoh, 2012).

Menurut Zaldi (2010), usaha kearah pembudidayaan ikan di perairan umum sangat diperlukan sebagai penyeimbang dan pembantu pemenuhan produksi ikan yang selama ini diperoleh dari hasil penangkapan yang cenderung semakin menurun. Seiring dengan berkembangnya zaman dan meningkatnya pertambahan penduduk yang diiringi dengan semakin meningkatnya kebutuhan protein hewani oleh manusia setiap tahunnya, maka perlu adanya peningkatan produksi ikan sebagai salah satu sumber pangan dan sumber protein. Peningkatan produksi perikanan dapat dilakukan dengan kegiatan pembudidayaan ikan di karamba jaring apung (KJA) dan karamba jaring tancap (KJT).

Karamba jaring tancap (KJT) adalah metode pemeliharaan ikan yang memiliki beberapa keunggulan dibandingkan dengan karamba jaring apung (KJA). Berikut ini adalah beberapa keunggulan metode karamba jaring tancap dibandingkan dengan karamba jaring apung, yaitu desain lebih mudah dan efisien dalam pembuatannya, dana yang diperlukan tidak terlalu besar, pengoperasiannya mudah, produktivitas lebih tinggi, tidak memerlukan kedalaman air yang terlalu dalam seperti karamba jaring apung (Direktorat Jenderal Perikanan Budi daya, 2014).

Sulawesi Utara dengan luas wilayah sebesar 2.748 .763 ha, potensi untuk lahan perairan umum sebesar \pm 28.500 ha yang terdiri dari danau 10.663 ha, rawa-rawa 13.712 ha dan sisanya sungai 4.125 ha. Danau Tondano dengan luas 4.278 ha merupakan perairan umum terbesar di Sulawesi Utara yang telah dimanfaatkan oleh masyarakat untuk budi daya ikan air tawar seperti ikan mas dan Nila dalam karamba jaring apung (KJA) dan karamba jaring tancap (KJT) serta budi daya ternak unggas air (itik). Masyarakat tani yang berada disekitar Danau Tondano banyak menggantungkan sumber pencaharian di perairan ini secara turun temurun (Diskan Sulut, 2000).

Desa Paslaten merupakan salah satu desa yang berada di sekitaran Danau Tondano, dimana ada beberapa keluarga menggantungkan hidupnya dalam mengusahakan budi daya ikan di karamba jaring tancap (Diskan Sulut, 2000).

Ikan Nila (Oreochromis niloticus) merupakan salah satu komoditas perikanan yang sangat popular di masyarakat. Selain harganya murah, rasanya enak, kandungan proteinnya juga cukup tinggi sehingga banyak pembudidaya yang membudidayakan ikan tersebut (Budiyanto, 2013).

Keuntungan yang bisa diambil dari peluang usaha ikan Nila diantaranya, memiliki pertumbuhan yang sangat cepat dan pesat menjadikan proses pemanenan ikan tersebut tergolong cepat, dan kelebihan lain dari ikan Nila yaitu dapat di budidayakan di tempat mana saja misalnya, bisa 
menggunakan karamba jaring tancap, karamba jaring apung, kolam ikan, di sawah dan masih banyak lainnya. Ikan Nila juga tahan terhadap serangan penyakit, dan tergolong ikan pemakan segalanya yang dapat berkembang baik dengan cara pemberian berbagai macam pakan termasuk limbah rumah tangga. Maka dari itu peluang usaha ini pun relatif lebih murah dan mudah (Anonim, 2014).

Produksi ikan Nila lima tahun terakhir berdasarkan data dari Dinas Kelautan dan Perikanan Provinsi Sulawesi Utara untuk tahun 2011-2015 produksi ikan Nila di Kabupaten Minahasa terus meningkat. Tahun 2011 produksi ikan Nila sebesar 19.142,7 ton, tahun 2012 sebesar 26.530,3 ton, tahun 2013 sebesar 43.011,71 ton, tahun 2014 sebesar 56.029,3 ton dan tahun 2015 sebesar 73.957,4 ton (Diskan Sulut, 2016).

Sehubungan dengan semakin meningkatnya produksi ikan maka para pembudidaya perlu mempertahankan dan mengembangkan usaha budi daya ikan Nila dengan sebaik mungkin agar pembudidaya tidak mengalami kerugian, untuk itu diperlukan suatu analisis kelayakan dari usaha tersebut.

\section{METODOLOGI PENELITIAN}

Metode yang digunakan dalam penelitian ini adalah deskriptif dengan dasar penelitiannya adalah survei. Ahmamud (2012) menyatakan survei adalah suatu metode yang dilakukan untuk mengumpulkan data, informasi dan keterangan-keterangan tentang subjek penelitian melalui pengamatan, menafsir, mencatat data sesuai dengan apa yang tersedia di lokasi penelitian.

Metode yang digunakan dalam pengambilan data ini adalah metode sensus dengan cara observasi langsung dimana populasi yang diambil adalah seluruh pembudidaya ikan Nila yang ada di Desa Paslaten Kecamatan Remboken, dimana pembudidayanya berjumlah lima kepala keluarga (KK). Ali (2014) menyatakan sensus adalah cara pengumpulan data apabila seluruh elemen populasi diselidiki satu per satu.

Data yang dikumpulkan berupa data primer dan data sekunder. Data primer diperoleh melalui pengamatan langsung pada obyek yang diteliti dan wawancara langsung dengan pemilik usaha ikan Nila sistem karamba jaring tancap yang ada di Desa Paslaten Kecamatan Remboken Kabupaten Minahasa. Data sekunder diperoleh dari Kantor Desa Paslaten dan tokoh-tokoh masyarakat serta berbagai sumber yang menjelaskan tentang keadaan Desa Paslaten.

Analisis data yang digunakan dalam penelitian ini adalah metode analisis deskriptif kualitatif dan metode analisis deskriptif kuantitatif serta analisis finansial untuk menentukan operating profit (OP), net profit ( $\pi)$, profit rate $(\mathrm{PR})$, benefit cost ratio $(\mathrm{BCR})$, rentabilitas, break even point (BEP) dan payback period (PP). 


\section{HASIL DAN PEMBAHASAN}

Keadaan Umum Pembudidaya Ikan Nila

Pembudidaya usaha karamba jaring tancap yang ada di Desa Paslaten berjumlah lima Kepala Keluarga (KK). Pada umumnya keadaan usaha budi daya ikan Nila sistem karamba jaring tancap di Desa Paslaten Kecamatan Remboken semuanya sama yaitu dengan dasar perairan yang berlumpur dan berpasir. Kedalaman air untuk usaha budi daya ikan Nila dengan menggunakan karamba jaring tancap di Desa Paslaten juga bervariasi mulai dari 5-15 meter. Usaha budi daya ikan sitem karamba jaring tancap di Desa Paslaten Kecamatan Remboken juga sering mengalami kendala akibat cuaca buruk, eceng gondok dan keadaan air yang tidak baik.

Cuaca sangat berpengaruh terhadap usaha budi daya di karamba jaring tancap karena sering kali pada saat cuaca buruk, arus angin yang cukup keras membuat bambu-bambu patah dan bambu-bambu tersebut merusak jaring dan ikan yang ada di dalam jaring keluar sehingga pembudidaya mengalami kerugian.

Eceng gondok merupakan tumbuhan yang tumbuh begitu banyak di sekitar danau Tondano. Eceng gondok ini juga menjadi kendala bagi pembudidaya dalam menjalankan usaha karena eceng gondok dapat merusak jaring ikan.

Keadaan air di Danau Tondano sering terjadi "Aer jaha" atau "Rano lewo" yang merupakan istilah dari orang Minahasa dan "Abu ele" yang merupakan istilah dari masyarakat Jawa Tondano. Keadaan air tersebut bisa mengakibatkan kematian masal ikan karena keadaan air tersebut dipengaruhi oleh angin Barat kemudian air menjadi dingin dan kadar oksigennya berkurang sehingga ikan tidak dapat beradaptasi dan ikan mudah mati jika hal tersebut terjadi maka pembudidaya akan mengalami kerugian.

Pada keadaan angin Barat maka para pembudidaya harus melihat keadaan karamba dan menggoyangkan jaring-jaring ikan atau memakai mesin seperti mesin alkon dan katinting agar ikan-ikan yang mereka budidayakan tidak mati, hal ini terjadi setiap $1-2 x$ dalam setahun.

\section{Usaha Budi Daya Ikan Nila Sistem Karamba Jaring Tancap \\ Modal Usaha}

Modal usaha yang dimiliki oleh lima pembudidaya ikan Nila sistem karamba jaring tancap di Desa Paslaten Kecamatan Remboken adalah modal sendiri dan modal awal untuk usaha budi daya ikan Nila ini berbeda-beda untuk setiap pembudidaya karena tidak semua pembudidaya memiliki jaring yang jumlahnya sama dan tidak semua pembudidaya juga mengeluarkan biaya yang sama untuk pembuatan rumah jaga, perahu dan peralatan. Modal yang mereka keluarkan tergantung dari 
berapa banyak jaring yang mereka buat dan berapa banyak pengeluaran untuk rumah jaga, perahu dan peralatan.

\section{Tenaga Kerja}

Hasil penelitian dari lima responden pembudidaya ikan Nila sistem karamba jaring tancap di Desa Paslaten Kecamatan Remboken mengenai tenaga kerja yang mereka pakai untuk membantu membudidayakan ikan Nila, ternyata tenaga kerjanya adalah bapak/ anak/ saudara mereka sendiri karena dengan menggunakan jasa tenaga kerja dari bapak/anak/saudara mereka sendiri maka mereka dapat mengurangi pengeluaran untuk pembayaran upah. Penggunaan jasa tenaga kerja dengan orang yang masih terikat sebagai keluarga tentu lebih murah dibandingkan dengan menggunakan jasa tenaga kerja orang lain.

\section{Pendederan Ikan Nila}

Pendederan adalah kegiatan pemeliharaan benih sampai ukuran tertentu hingga siap untuk dipelihara. Berdasarkan hasil wawancara dari lima orang pembudidaya yang ada diketahui bahwa pembudidaya ikan Nila sistem karamba jaring tancap di Desa Paslaten Kecamatan Remboken membeli benih ikan Nila dari Desa Tatelu. Benih ikan yang dibeli dari Desa Tatelu dimasukkan kedalam jaring ukuran $3 \times 3$ sebanyak 500 - 1000 ekor benih dan jaring ukuran $4 \times 4$ sebanyak 1000 - 1250 ekor benih. Benih yang dimasukkan kedalam jaring adalah benih yang berukuran kurang dari $10 \mathrm{~cm}$ yaitu ukuran $6-8 \mathrm{~cm}$. Pembudidaya membeli benih ikan Nila dengan ukuran perekor, ukuran $6-8 \mathrm{~cm}$ harganya $\mathrm{Rp}$. 600/ekor.

Lamanya pendederan benih ikan Nila yang dilakukan oleh pembudidaya yang ada di Desa Paslaten yaitu selama 3-4 minggu kemudian disortir untuk di pindahkan ke jaring yang lain sesuai dengan ukuran. Ukuran lebar badan ikan sebesar 2-3 jari akan di pindahkan ke jaring yang lain dan untuk ukuran dibawah 2 jari di pindahkan juga ke jaring yang berbeda.

\section{Pembesaran Ikan Nila}

Pembudidaya yang ada di Desa Paslaten melakukan pembesaran ikan Nila di karamba jaring tancap dengan ukuran $3 \times 3$ dimasukkan ikan sebanyak 250 - 500 ekor dan ukuran $4 \times 4$ dimasukkan ikan sebanyak 500 - 1000 ekor. Ikan Nila yang dipelihara dalam karamba jaring tancap diberikan pakan berupa pelet hingga ikan layak untuk dikonsumsi. Pemberian pakan pada ikan Nila diberikan 2 kali dalam sehari yaitu pada pagi dan sore hari, akan tetapi jika keadaan air yang ada di danau Tondano terjadi "aer jaha" maka ikan-ikan tersebut tidak boleh diberikan pakan karena jika diberikan pakan ikan-ikan tersebut akan mati, itu berarti pembudidaya mengalami kerugian.

Pembesaran ikan Nila sistem karamba jaring tancap dari ukuran benih 
sampai ikan layak dikonsumsi memerlukan waktu empat bulan jadi setiap tahunnya pembudidaya panen tiga kali.

\section{Pemasaran Ikan Nila}

Pembudidaya ikan Nila sistem karamba jaring tancap di Desa Paslaten Kecamatan Remboken menjual ikan Nila ke pedagang pengumpul dan rumah makan yang biasanya sudah menjadi langganan mereka. Biasanya langganan pembeli ikan Nila langsung datang ke rumah untuk membeli ikan Nila. Selain itu ikan Nila juga dijual ke pasar-pasar seperti Pasar Tondano, Pasar Tomohon, Pasar Langowan dan Pasar Kawangkoan, dengan harga jual Rp. $25.000 / \mathrm{kg}$.

\section{Analisis Kelayakan Usaha Budi Daya Ikan Nila Sistem Karamba Jaring Tancap di Desa Paslaten}

\section{Modal Investasi}

Modal merupakan hal yang penting yang harus disediakan oleh pelaku usaha untuk menjalankan usahanya, yang merupakan dana awal dalam pembentukkan usaha. Modal investasi yang dibutuhkan oleh lima pembudidaya ikan Nila sistem karamba jaring tancap di Desa Paslaten Kecamatan Remboken dapat dilihat pada tabel berikut.
Tabel 1. Rata-rata Modal Investasi Pembudidaya Ikan Nila Sistem Karamba Jaring Tancap di Desa Paslaten

\begin{tabular}{|c|l|r|r|r|}
\hline No. & $\begin{array}{c}\text { Modal } \\
\text { Investasi }\end{array}$ & $\begin{array}{c}\text { Jumlah } \\
\text { (Unit) }\end{array}$ & $\begin{array}{c}\text { Harga } \\
\text { Satuan } \\
\text { (juta } \\
\text { Rp) }\end{array}$ & $\begin{array}{c}\text { Jumlah } \\
\text { (juta } \\
\text { Rp) }\end{array}$ \\
\hline 1. & Rumah jaga & 1 & 14,4 & 14,4 \\
\hline 2. & Jaring & 20 & 0,8 & 15,5 \\
\hline 3. & Perahu & 1 & 5,8 & 6,9 \\
\hline 4. & Mesin & 1 & 2,4 & 2,4 \\
\hline 5. & Serok besar & 1 & 0,2 & 0,2 \\
\hline 6. & Timbangan & 1 & 0,2 & 0,2 \\
\hline \multicolumn{4}{|c|}{ Total } \\
\hline
\end{tabular}

Sumber : Hasil Penelitian 2016

\section{Tingkat pendapatan}

Seorang pengusaha tentunya mengharapkan pendapatan yang lebih atau keuntungan yang besar dalam menjalankan suatu usaha. Pendapatan pembudidaya ikan Nila sistem karamba jaring tancap yang ada di Desa Paslaten Kecamatan Remboken tergantung dari berapa banyak ikan yang diproduksi dan harga jual ikan Nila per kilo.

Berdasarkan hasil penelitian dari lima responden yang ada di Desa Paslaten Kecamatan Remboken Kabupaten Minahasa, jumlah pendapatan rata-rata pembudidaya adalah sebesar Rp. 133.025.000 per tahun yang diperoleh dari rata-rata jumlah produksi dikali dengan harga jual (5.321 x Rp. 25.000). Pendapatan adalah pendapatan kotor yang belum dikurangi biaya tetap dan biaya tidak tetap.

\section{Struktur Biaya}

Biaya produksi dapat didefinisikan bahwa semua pengeluaran yang dilakukan oleh perusahaan untuk memperoleh faktor-faktor produksi dan 
bahan-bahan mentah yang akan digunakan untuk menciptakan barangbarang yang diproduksikan perusahaan tersebut (Sukirno, 2013). Selain modal investasi para pembudidaya yang ada di Desa paslaten Kecamatan Remboken juga harus menyediakan biaya-biaya lain, yaitu biaya tetap dan biaya tidak tetap.

1) Biaya Tetap (Fixed Cost)

Biaya tetap adalah keseluruhan biaya yang dikeluarkan untuk memperoleh faktor produksi yang tidak dapat diubah jumlahnya (Sukirno, 2013). Biaya tetap pada usaha budi daya ikan Nila sistem karamba jaring tancap yang ada di Desa Paslaten Kecamatan Remboken terdiri atas biaya perawatan dan biaya penyusutan. Biaya tetap untuk usaha budi daya ikan Nila dapat dilihat pada tabel berikut.

Tabel 2. Biaya Tetap Usaha Budi Daya Nila Sistem Karamba Jaring Tancap di Desa Paslaten

\begin{tabular}{|c|l|r|}
\hline No. & \multicolumn{1}{|c|}{ Jenis } & \multicolumn{1}{c|}{ Jumlah (Rp) } \\
\hline & Perawatan & 272.000 \\
\hline 1. & Perawatan rumah jaga & 330.000 \\
\hline 2. & Perawatan jaring & 300.000 \\
\hline 3. & Perawatan perahu & 1.440 .000 \\
\hline & Penyusutan & 2.657 .600 \\
\hline 1. & Penyusutan rumah jaga & 1.392 .000 \\
\hline 2. & Penyusutan jaring & 488.000 \\
\hline 3. & Penyusutan perahu & 40.000 \\
\hline 4. & Penyusutan mesin & 216.000 \\
\hline 5. & Penyusutan timbangan & 7.569 .704 \\
\hline 6. & Rekening listrik & Total \\
\hline \multicolumn{2}{|c|}{}
\end{tabular}

2) Biaya Tidak Tetap (Variable Cost) Keseluruhan biaya yang dikeluarkan untuk memperoleh faktor produksi yang dapat diubah jumlahnya (Sukirno, 2013). Rata-rata biaya tidak tetap untuk usaha budi daya ikan Nila sistem karamba jaring tancap di Desa Paslaten Kecamatan Remboken dapat dilihat pada tabel berikut.
Tabel 3. Biaya Tidak Tetap Usaha Budi Daya Ikan Nila Sistem Karamba Jaring Tancap di Desa Paslaten

\begin{tabular}{|c|l|c|r|r|}
\hline No. & Jenis & $\begin{array}{c}\text { Jumlah } \\
\text { (Satuan) }\end{array}$ & $\begin{array}{c}\text { Harga } \\
\text { Satuan } \\
\text { (Rp) }\end{array}$ & Jumlah Rp) \\
\hline 1. & $\begin{array}{l}\text { Tenaga } \\
\text { kerja }\end{array}$ & 2 orang & 2.355 .000 & 5.181 .000 \\
\hline 2. & Pakan & $\begin{array}{c}96 \\
\text { karung }\end{array}$ & 450.000 & 43.020 .000 \\
\hline 3. & Benih & $\begin{array}{c}18.600 \\
\text { ekor }\end{array}$ & 600 & 11.160 .000 \\
\hline 4. & Obat & 1 botol & 100.000 & 100.000 \\
\hline \multicolumn{4}{|c|}{ Total } & 59.461 .000 \\
\hline
\end{tabular}

Sumber Hasil Penelitian 2016

Total Biaya $(\mathrm{TC}) \quad=$ TFC + TVC

$=$ Rp. $7.569 .704+$ Rp. 59.461 .000

$=$ Rp. 67.030 .704

Total biaya (TC) adalah keseluruhan biaya yang dikeluarkan untuk kegiatan proses produksi. Total biaya dari usaha budi daya ikan Nila sistem karamba jaring tancap yang ada Desa Paslaten Kecamatan Remboken adalah sebesar Rp. 67.030.704. total biaya ini diperoleh dari total biaya tetap (fixed cost) ditambah dengan total biaya tidak tetap (variabel cost).

\section{Analisis Kelayakan}

Guna mengetahui kelayakan dari usaha budidaya ikan Nila system karamba jaring tancap di Desa Paslaten Kecamatan Remboken, maka hal yang harus diketahui terlebih dahulu adalah :

Guna mengetahui kelayakan dari usaha budidaya ikan Nila system karamba jaring tancap di Desa Paslaten Kecamatan Remboken, maka hal yang harus diketahui terlebih dahulu adalah :

$\begin{array}{lll}\text { Investasi (I) } & =\text { Rp. } 39.608 .520 \\ \text { Biaya Tetap (FC) } & =\text { Rp. } 7.569 .704 \\ \text { Biaya Tidak Tetap (VC) } & =\text { Rp. } 59.461 .000 \\ \text { Total Biaya (TC) } & =\text { Rp. } 67.030 .704 \\ \text { Total Penerimaan (TR) } & =\text { Rp. } 133.025 .000\end{array}$


Guna mengetahui tingkat kelayakan usaha digunakan analisis finansial dengan menggunakan rumus :

1) $\mathrm{OP}=\mathrm{TR}-\mathrm{VC}$

Dimana :

$\mathrm{TR}=$ Total penerimaan

$\mathrm{VC}=$ Biaya tidak tetap

$\mathrm{OP}=\mathrm{TR}-\mathrm{VC}$

$=$ Rp. $133.025 .000-$ Rp. 59.461 .000

$=$ Rp. 73.564 .000

Operating profit dari usaha budi daya ikan Nila sistem karamba jaring tancap di Desa paslaten Kecamatan Remboken sebesar Rp. 73.564.000 merupakan keuntungan yang diperoleh dan dapat digunakan untuk biaya produksi berikutnya.

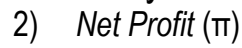

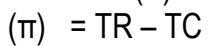

$$
\begin{aligned}
& \text { Dimana : } \\
& \mathrm{TR}=\text { Total penerimaan } \\
& \mathrm{TC}=\text { Total biaya }
\end{aligned}
$$

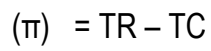

$$
\begin{aligned}
& =\text { Rp. } 133.025 .000-\text { Rp. } 67.030 .704 \\
& =\text { Rp. } 65.994 .296
\end{aligned}
$$
absolut usaha ini sebesar Rp. 65.994.296. Keuntungan ini menggambarkan bahwa usaha budi daya ikan Nila sistem karamba jaring tancap di Desa Paslaten Kecamatan Remboken dijamin keberlangsungannya, karena hasil menunjukkan angka positif.

3) Profit Rate (PR)

$$
\begin{aligned}
& \text { Profit rate }=\frac{\pi}{T C} \times 100 \\
& \text { Dimana : } \\
& \text { (ז) }=\text { Total profit } \\
& \mathrm{TC}=\text { Total Biaya } \\
& \text { Profit rate }=\frac{\pi}{T C} \times 100 \\
& =\frac{\mathrm{Rp} \cdot 65,994,296}{\mathrm{Rp} \cdot 67.030 .704} \times 100 \\
& =98,45 \%
\end{aligned}
$$

Tingkat keuntungan menunjukkan usaha budi daya ikan Nila sistem karamba jaring tancap di Desa Paslaten
Kecamatan Remboken memberikan keuntungan dibandingkan dengan jumlah keseluruhan biaya yang dikeluarkan. Tingkat keuntungan yang didapat sebesar $98,45 \%$ yang berarti usaha yang dijalankan mendatangkan keuntungan.

4) Benefit Cost Ratio (BCR)

$$
\begin{aligned}
\text { BCR } & =\frac{T R}{T C} \\
\text { Dimana }: & \\
\text { TR } & =\text { Total penerimaan } \\
\text { TC } & =\text { Total biaya } \\
\text { BCR } & =\frac{T R}{T C} \\
& =\frac{\text { Rp. } 133.025 .000}{\text { Rp } \cdot 67.030 .704} \\
& =1,98
\end{aligned}
$$

BCR yang didapat oleh pembudidaya ikan Nila sistem karamba jaring tancap di Desa Paslaten Kecamatan Remboken adalah 1,98. Dengan Nilai BCR 1,98 maka usaha ini layak untuk dijalankan karena penerimaan lebih besar daripada biaya yang dikeluarkan $(B / C>1$ atau $B>$ C). Jadi usaha budi daya ini memberikan keuntungan sebesar 1,98 dari seluruh biaya yang dikeluarkan.

5) Rentabilitas

$$
\text { Rentabilitas }=\frac{\pi}{l} \times 100
$$

$$
\begin{aligned}
& \text { Dimana : } \\
& \pi \quad=\text { Total profit } \\
& \text { I = Investasi } \\
& \text { Rentabilitas }=\frac{\pi}{I} \times 100 \\
& =\frac{\text { Rp. } 65.994 .296}{\text { Rp. } 39.568 .000} \times 100 \\
& =166 \%
\end{aligned}
$$

Besarnya rentabilitas pada usaha budi daya ikan Nila system karamba jaring tancap di Desa Paslaten Kecamatan 
Remboken yaitu sebesar 166\% menunjukkan usaha yang dijalankan termasuk dalam kategori baik sekali karena $>100 \%$. Jadi kemampuan usaha budi daya ikan Nila ini dapat menghasilkan keuntungan sebesar $166 \%$ dari investasi yang ada.

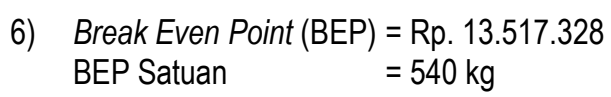

BEP penjualan sebesar Rp. 13.517.328 dan BEP satuan $540 \mathrm{~kg}$, artinya kegiatan usaha budi daya ikan Nila sistem karamba jaring tancap di Desa Paslaten Kecamatan Remboken akan mengalami titik impas apabila telah menjual sebanyak $540 \mathrm{~kg}$ dengan harga jual ikan sebesar Rp. 13.517.328.

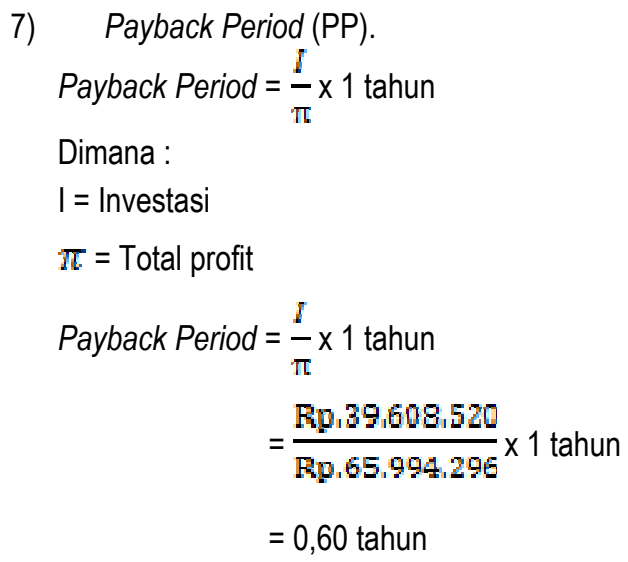

Jangka waktu pengembalian investasi dari usaha budi daya ikan Nila sistem karamba jaring tancap di Desa Paslaten Kecamatan Remboken adalah 0,60 tahun. 0,60 tahun dihitung dalam bulan, yaitu $0,60 \times 12$ bulan $=7,2$ bulan. 7,2 bulan dihitung dalam hari, yaitu $0,2 \times 30$ hari $=6$. Jadi, 7,2 bulan atau tujuh bulan enam hari. Jangka waktu pengembalian investasi dari usaha budi daya ikan Nila sistem karamba jaring tancap di Desa Paslaten yaitu tujuh bulan enam hari.

\section{KESIMPULAN DAN SARAN Kesimpulan}

Berdasarkan hasil penelitian usaha budi daya ikan Nila sistem karamba jaring tancap di Desa Paslaten Kecamatan Remboken dapat disimpulkan bahwa rata-rata modal investasi dari lima pembudidaya sebesar Rp. 39.608.520 dan total biaya sebesar Rp. 67.030 .704 dengan rata-rata pendapatan sebesar Rp. 133.025.000 per tahun yang diperoleh dari rata-rata jumlah produksi dikali dengan harga jual (5.321x Rp. 25.000).

Hasil perhitungan pada usaha budi daya ikan Nila sistem karamba jaring tancap di Desa Paslaten Kecamatan Remboken meliputi perhitungan Nilai operating profit (OP) sebesar Rp. 73.564.000, net profit atau keuntungan absolut sebesar Rp. 65.994.296, profit rate sebesar $98,45 \%$, benefit cost ratio (BCR) lebih dari 1 yaitu 1,98 , rentabilitas lebih dari $100 \%$ yaitu $166 \%$, BEP penjualan sebesar Rp. 13.517.328 dan BEP satuan $540 \mathrm{~kg}$ dengan jangka waktu pengembalian 7,2 atau tujuh bulan enam hari. Berdasarkan perhitungan tersebut maka usaha budi daya ikan Nila sistem karamba jaring tancap di Desa Paslaten Kecamatan Remboken layak untuk dijalankan. 


\section{Saran}

1. Sebaiknya untuk karamba jaring tancap yang sudah rusak harus diperbaiki kembali dan membuang bambu-bambu yang sudah rusak agar bambu-bambu tersebut tidak merusak jaring milik sendiri maupun jaring milik orang lain.

2. Sebaiknya pembudidaya ikan Nila sistem karamba jaring tancap di Desa Paslaten membuat catatan mengenai jumlah pengeluaran dan pemasukkan setiap panen.

3. Sebaiknya pembudidaya ikan Nila sistem karamba jaring tancap di Desa Paslaten membuat pakan sendiri atau menyiapkan pakan alternatif agar pengeluaran untuk biaya pakan tidak banyak, karena pengeluaran untuk pakan $60-70 \%$.

\section{DAFTAR PUSTAKA}

Ali, 2014. Pengertian Sensus dan Sampling Dalam Statistik.

http://www.pengertianpakar.com/2014/11/peng ertian-sensus-dan-sampling-dalam.html (Diakses 16 Mei 2016)

Anonim, 2014. Analisis Usaha Ikan Nila. http://www.analisausaha.net/analisa-usahaikan-Nila/ (Diakses pada 20 Mei 2016)

Dahuri, R., J. Rais. S. P. Ginting dan M. J. Sitepu. 2001. Pengelolaan sumberdaya wilayah pesisir dan lautan secara terpadu. Pradnya Parafma, Jakarta.

Dinas Perikanan Provinsi Sulawesi Utara. 2000. Informasi Perikanan. Dinas PerikananProvinsi Sulawesi Utara, Manado

Dinas Perikanan Provinsi Sulawesi Utara. 2016. Statistik Perikanan Budi daya Provinsi Sulawesi Utara. Dinas Perikanan Provinsi Sulawesi Utara, Manado

Nawawi. 1987. Metode Penelitian Bidang Sosial. Universitas Gadja Mada. Yogyakarta.

Sukirno. 2013. Mikroekonomi. Teori Pengantar. PT. Rajagrafindo Persada Jakarta

Zaldi, S. 2010. Pemanfaatan Aliran Sungai Untuk Usaha Budi daya Ikan Nila Gesit Dalam Karamba Jaring Tancap di Desa Semperiuk Kecamatan Jawa Selatan Kabupaten Sambas. 